\title{
Two Propane Gas Supplier Workers Electrocuted when Boom Truck Crane's Boom Contacts 7,200 Volt Overhead Power Line
}
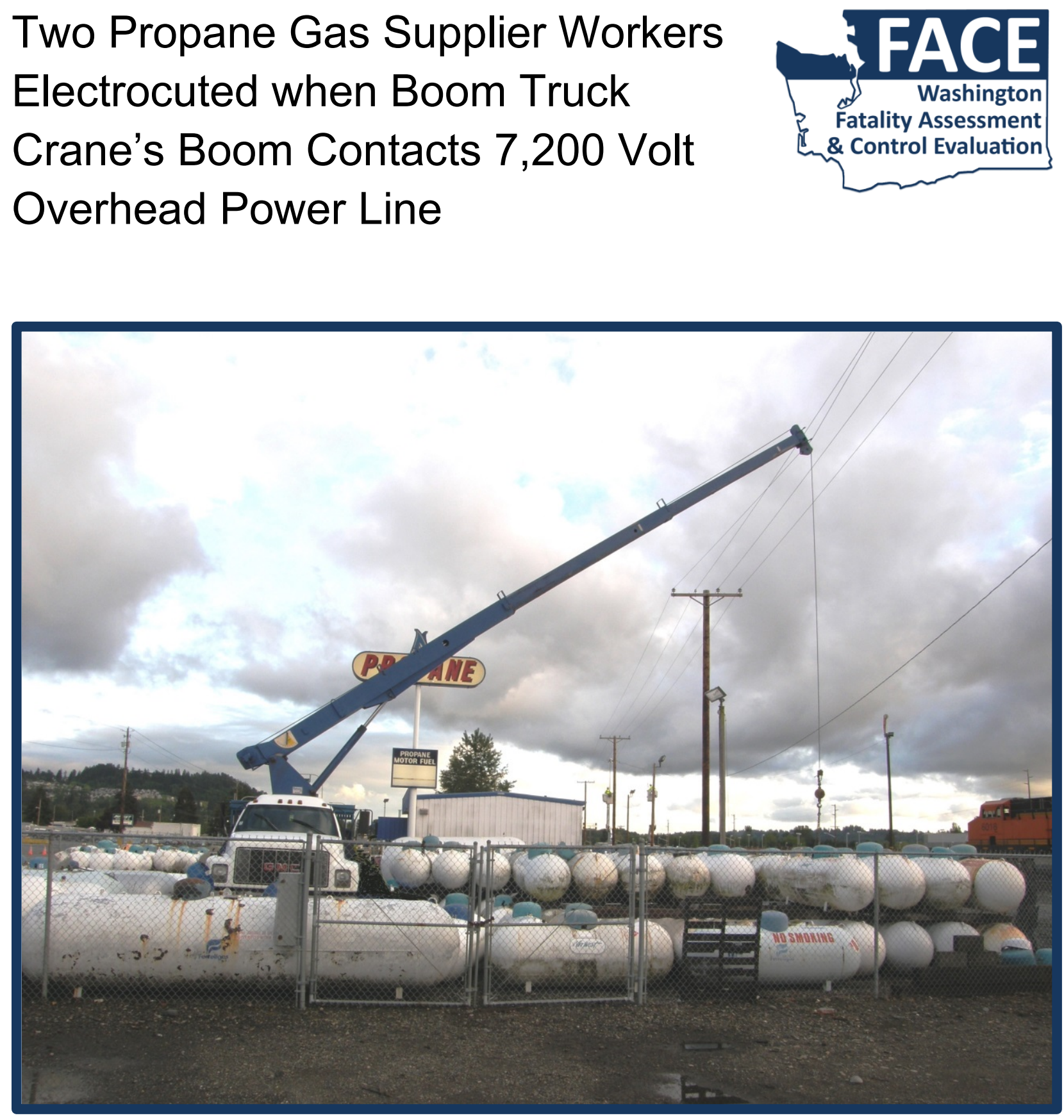

Investigation: \# 10WA031

Release Date: April 21, 2015

SHARP Report: \# 52-32-2015 
TABLE OF CONTENTS

CONTENTS

PAGE

SUMMARY

3

RECOMMENDATIONS

4

INTRODUCTION

Employer $\quad 5$

Employer Safety Program and Training 5

Victims $\quad 6$

$\begin{array}{ll}\text { Equipment } & 7\end{array}$

$\begin{array}{lr}\text { Incident Scene } & 9\end{array}$

$\begin{array}{ll}\text { Weather } & 11\end{array}$

$\begin{array}{ll}\text { INVESTIGATION } & 11\end{array}$

$\begin{array}{ll}\text { CAUSE OF DEATH } & 17\end{array}$

$\begin{array}{ll}\text { CONTRIBUTING FACTORS } & 17\end{array}$

$\begin{array}{ll}\text { POST-INCIDENT CORRECTIVE ACTIONS BY EMPLOYER } & 17\end{array}$

RECOMMENDATIONS AND DISCUSSION 19

REFERENCES AND TRAINING MATERIALS 25

$\begin{array}{lr}\text { INVESTIGATOR INFORMATION } & 27\end{array}$

$\begin{array}{lr}\text { FACE PROGRAM INFORMATION } & 28\end{array}$

$\begin{array}{lr}\text { ACKNOWLEDGMENTS } & 28\end{array}$ 


\section{SUMMARY}

In May of 2010, a 40-year-old propane service technician and a 25-year-old material handler were electrocuted at a propane gas supplier's tank storage yard when a boom truck crane's boom contacted an overhead power line. The incident occurred as the service technician operating the crane was preparing to lift a tank. The two victims were employed by a large national retail and wholesale supplier of propane. They worked at their employer's propane service center and regional office location. This plant location provided a variety of propane services including bulk fuel delivery, tank and cylinder delivery and installation, service location fuel sales, and appliance sales, service, and repair.

On the day of the incident, the service technician and material handler were making an annual inventory of previously used propane bulk storage tanks. These tanks were located in the tank storage yard portion of the propane service center plant. Some of the tanks were stacked two-high and placed in rows. The information that they needed for the inventory was located on the top of the tanks. In order to access the tanks on the bottom they were using a telescopic boom truck crane to lift the top tanks. The material handler rigged the tanks with a metal chain so that they could be lifted by the crane. When the service technician who was operating the crane lifted the tank, the material handler was then able to obtain and write down the necessary inventory information on sheets that he was carrying on a clip board.

The material handler rigged a tank to be lifted. This tank was located at the end of a row of 320-gallon capacity tanks adjacent to a fence marking the yard's boundary. Just beyond the fence, a 3-phase 7,200 volt overhead power distribution line, crossed over into the yard at a diagonal by a few feet at this location. The service technician proceeded to position the crane boom for the lift. As he was doing so, the tip of the fully extended boom contacted one of the power line wires. Electrical current traveled down the boom to the truck and the metal grating of the crane operator's station where the service technician was standing. He died instantly when he stepped from the station to the ground, with one foot on the station and one foot on the ground, thereby creating a pathway for the current to move from the crane through his body to the ground. The boom remained in contact with the power line, creating a constant flow of voltage through the crane to the ground. The intensity of the electrical current caused the truck's tire's, nearby tanks, and adjacent ground to catch fire. The area where the material handler stood between two rows of tanks was about 28 feet from the truck. This area was not energized. He then went toward his coworker, presumably to provide aid, and entered the electrical field where he too was electrocuted. 


\section{RECOMMENDATIONS}

To prevent similar occurrences in the future, Washington State Fatality Assessment and Control Evaluation (FACE) investigators concluded that to protect employees from the hazard of electrocution from overhead power lines propane gas suppliers and other employers using cranes should follow these guidelines:

- Conduct a site survey to identify the locations of overhead power lines and determine whether work tasks could expose crane operators or ground workers performing material handling activities to the hazard of electrocution through boom, rigging, hoist line, or load contact with overhead power lines.

- Determine measures to be taken so that the hazard of power line electrocution may be avoided, eliminated, reduced, or controlled. Follow existing OSHA regulations and safe work practices.

- Develop, implement, and enforce a comprehensive written safety program for all workers. The safety program should include training for all crane operators and ground workers in overhead power line electrocution hazard recognition and safe work procedures. Training should also include crane operator power line visual limitations and perception issues, as well as emergency procedures should power line contact occur.

- Consider purchasing cranes with safety features intended to prevent or minimize the risk of electrocution. Alternatively, consider installing aftermarket safety accessories. 


\section{INTRODUCTION}

In May of 2010, the Washington FACE Program was notified by the Washington State Department of Labor and Industries Division of Occupational Safety and Health (DOSH) of the deaths of a 40-year-old propane service technician and a 25-year-old material handler. The victims, employed by a company selling propane gas, were making an inventory of propane bulk storage tanks at a service center yard. The service technician who was operating a boom truck crane to lift the tanks was electrocuted when the crane's boom tip contacted a 7,200 volt overhead power line. The material handler went toward him, presumably to provide aid, and entered the electrical field where he too was electrocuted.

In August of 2012, Washington State FACE investigators went to the company's office and interviewed the regional manager. During the course of the investigation, investigators reviewed documents including the victims' death certificates, autopsy reports, and the DOSH investigation file.

\section{Employer}

The employer is an affiliate of a large national retail and wholesale seller of propane gas. Propane services they provide include bulk fuel delivery, cylinder and tank delivery and installation, service location fuel sales, and appliance sales, service, and repair. They provide services to residential, commercial, construction, and agricultural customers. Founded in 1939, they have over 5,000 employees working at hundreds of locations nationally. In Washington State they have nearly two dozen locations. The employer company is $51 \%$ employee owned.

The incident site was at a regional office and service location which had oversight responsibility for several service locations in the service area. Within this service area there were 35 employees. Six employees had the job title of "service technician" and three had the job title of "material handler." The employer had been at this site for five years.

\section{Employer Safety Program and Training}

The employer had a formal, written Accident Prevention Program (APP), as required by law in Washington State. According to the company regional general manager, at the time of the incident, crane safety was reviewed perhaps two or three times per year at safety meetings, but there was no formal, in-depth training about safe crane operation and the hazards of overhead power lines. Their APP safety manual mentioned crane safety, but was not comprehensive in its approach, according to the general manager. There was a company regional operations and safety manager who spent about $80 \%$ of 
his time on safety related issues. He reported to the general manager. There was no standard operating procedure for tank inventory, the task the victims were performing.

\section{Victims}

\section{Service technician}

The 40-year-old service technician had worked for the employer over 4 years. His primary job duties included driving a boom truck to make deliveries of propane tanks to customer locations where he would then install them and set gas lines to make them operational; service and repair propane appliances for residential and retail customers; check tanks for leaks and do repairs; and provide propane system attachments to customers.

He had a class "A" Commercial Driver License (CDL) and was Hazmat and forklift operator certified. Previous to this job he had worked for 15 years as a class "A" CDL tow truck driver. According to the regional general manager, he had gained considerable on-the-job training and experience during the approximately three years he had operated and rigged company boom truck cranes. He had received no formal training in crane operation, nor had his crane-related knowledge and abilities been formally tested. Part of his service technician training with the employer did include awareness of electrocution hazards and safe operating distances while working with a crane near power lines. He had operated the incident crane many times and was considered by the general manager to be a very competent and exceptionally safe operator. This crane was almost solely used by him and no one at the company was as familiar with its operation as he was. According to the general manager, he was aware of the electrocution hazard of a crane making contact with overhead power lines. He had refused to make customer tank deliveries to sites where he believed power line proximity was a concern.

\section{Material handler}

The 25-year-old material handler had worked for the employer for 3 years. His job responsibilities included inspecting, repairing, refurbishing, filling, and loading propane cylinders for company delivery drivers, as well as customers who would come to their service location; assisting the service technicians; keeping service center office, plant and yard organized; and helping with propane tank inventory. His previous job experience included working as a traffic control flagger and a lawn mower repairer. While working for the employer he had frequently rigged propane tanks for lifts by forklifts, but had not performed rigging for lifts by cranes. He had received no formal training about what to do if a crane contacts an overhead power line. 
At the time of the incident, both victims were performing what their employer considered to be their normal job duties.

\section{Equipment}

The equipment involved in this incident was a boom truck crane (see photo 1). The incident crane was a common type of truck-mounted crane widely used in the propane industry. This industry typically uses flatbed trucks with either a telescopic boom crane or an articulating boom (knuckle boom) crane. This crane was an 8-ton boom truck crane that had a hydraulically operated telescopic boom, also known as a stick boom. It did not have a jib attached to the boom. The crane and its components were mounted on a commercial flatbed truck chassis. The maximum lift capacity of the crane was $16,000 \mathrm{lbs}$. and its fully extended boom reached 47 feet. There were crane operator stations located on elevated metal platforms on each side of the truck behind the cab (see photo 2). Seven stickers with signage warning of the hazard of electrocution were located on various parts of the crane (see photo 3). Manufactured in 1996, the boom truck crane was purchased new.

The boom truck crane was used to lift and move propane tanks in the company yard. It was also used to lift, move, and install propane tanks at customer locations. With a heavier lift capacity and a longer boom than most of the company's boom truck crane fleet, this crane was used for specific customer needs, such as large tank delivery. It had previously been used during the company's annual tank inventory at its tank storage yard, including in the area where the fatal incident occurred.

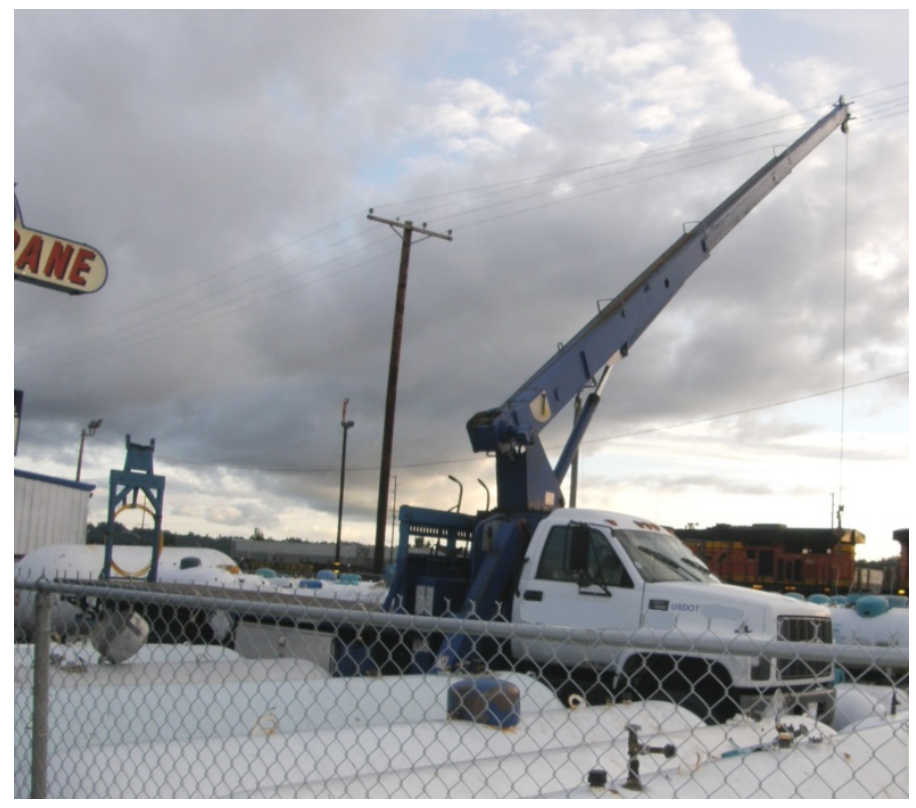

Photo 1. 8-ton boom truck crane with telescopic boom extended at incident site in employer's propane tank storage yard. 


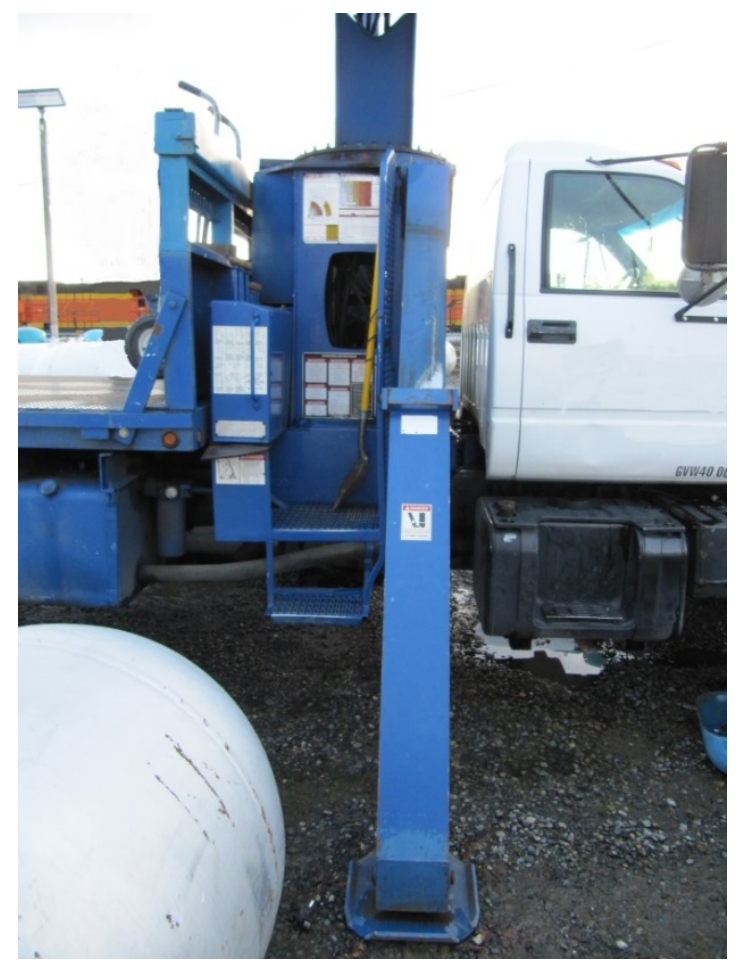

Photo 2. Crane operator's station on boom truck. Operator's stations were located on each side of the truck's chassis. This photo shows the station on the opposite side of the truck from where the service technician was standing at the time of the incident.

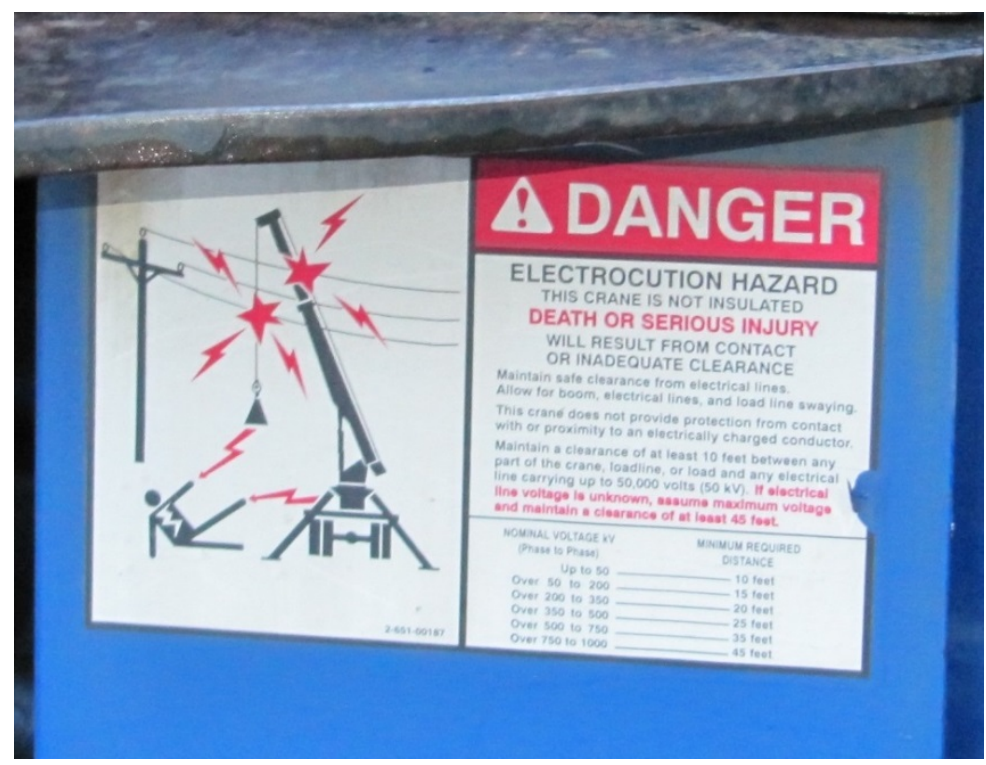

Photo 3. Safety sticker warning of electrocution hazard placed on the right side of the crane operator's station on the boom truck. There were seven such warning signs located on various parts of the boom truck. 


\section{Incident Scene}

The incident took place in a propane tank storage yard on the premises of the employer's local service center facility and regional office (see photos 4 and 5). Located on the premises were buildings containing an office, repair shop, customer fuel service depot with a loading dock, and a storage yard. In the yard there were propane bulk storage tanks and cylinders of various sizes and capacities. The facility was located on a narrow, roughly rectangular piece of property bounded on the east side by a four lane municipal street, on the south by a vacant lot, and on the west and north sides by property owned by a railroad company. The land on which the facility was located was property leased from this railroad company. The employer had been at this location for 5 years; previously, another propane supplier had operated at that site for 12 years.

A 3-phase, 7,200 volt overhead power distribution line owned by the railroad company ran north and south just beyond the facility's chain-link fenced western boundary. At the northwest corner of the facility, where the victims were working in the tank storage yard taking inventory of the tanks, the power line crossed over a few feet into the yard at a diagonal.

The yard contained dozens of previously used propane storage cylinders and tanks of various sizes. Many of the tanks, due to lack of storage space, were stacked two-high in rows. Some of these cylinders and tanks contained residual fuel and others were empty. If determined to be serviceable, these cylinders and tanks would be reconditioned and sold to customers. The strip of yard where the incident occurred was located in the north part of the company facility; it was approximately 58 feet wide, measured from the western fence to the eastern fence. The area where the victims were working at the time of the incident was in a row of 320-gallon capacity propane bulk storage tanks stacked two-high.

The yard surface was composed of dirt and gravel. There were puddles on the ground and all surfaces in the yard were wet due to showers during the day. 


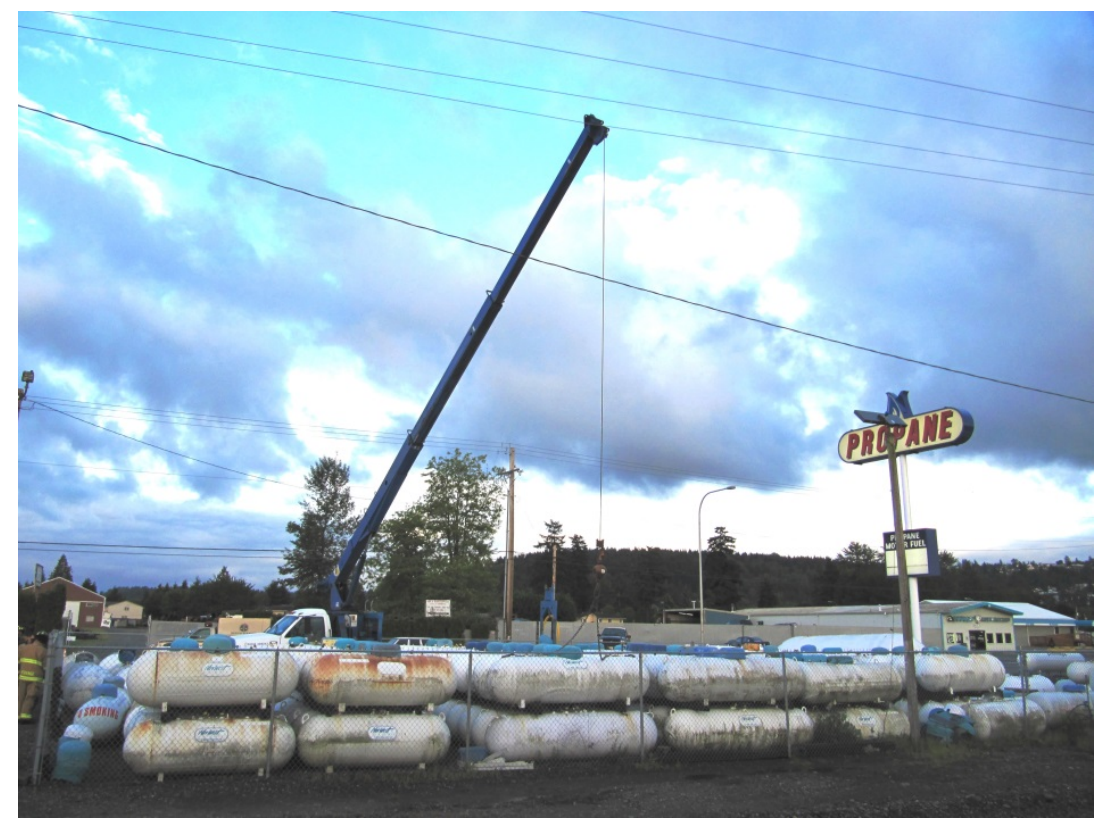

Photo 4. Incident site showing the employer's propane tank storage yard with 320-gallon capacity propane bulk storage tanks that the victims were inventorying. The photo was taken after the crane boom made contact with the energized 7,200 volt power line.

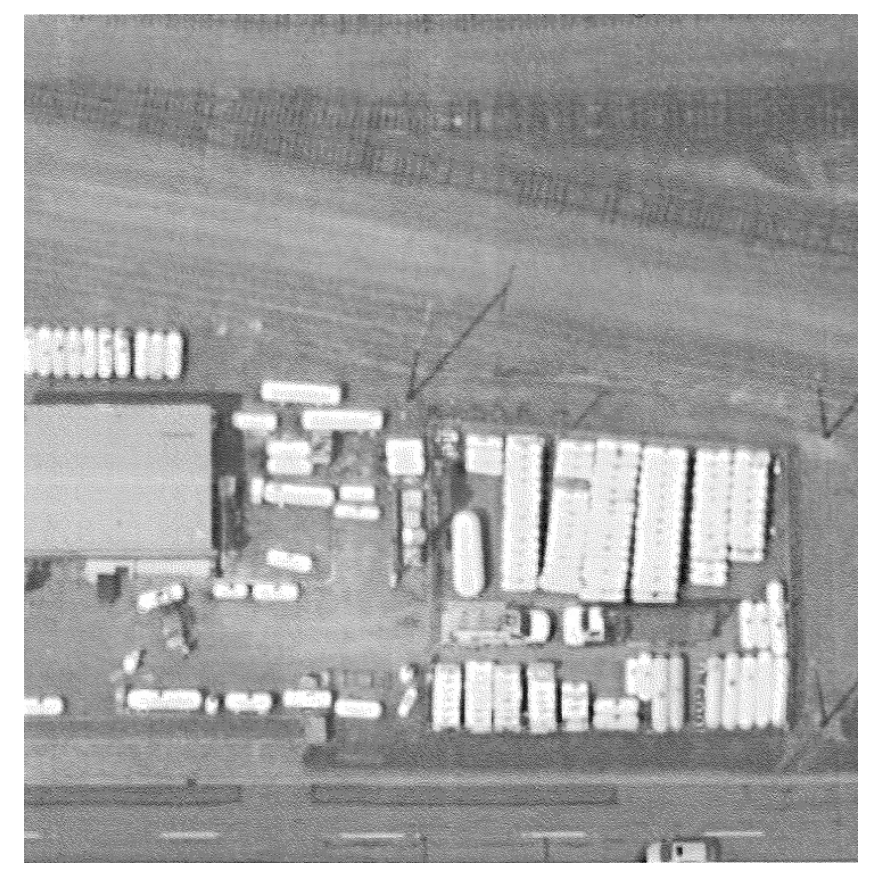

Photo 5. Aerial view of the north end of the employer's service center's propane tank storage yard where the incident occurred. This photo was not taken at the time of the incident, but shows the yard's general configuration. (Photo courtesy of Google) 


\section{Weather}

The weather at the time of the incident was mostly cloudy with a temperature of 55 degrees Fahrenheit and a wind speed of 10.4 miles per hour. Throughout the day there had been periods of rain. ${ }^{1}$

\section{INVESTIGATION}

On the day of the incident in May of 2010, the service technician and the material handler were assigned by the plant supervisor to conduct an inventory of propane cylinders and bulk storage propane tanks stored in the company service center yard. This inventory was done annually.

In order to carry out the inventory, the service technician and the material handler worked together. The information that they were collecting included the tank's size, condition, manufacturer, serial and barcode number, and percentage of residual fuel left in the tank. These data were collected by reading a metal plate inscribed with this information and consulting a fuel percentage gauge, both of which were centrally located on top of the tank beneath a metal dome shaped lid used to protect the tank's valves. The material handler would collect all of this information by writing it down on forms that he carried on a clip board.

Some of the tanks were 320-gallon capacity tanks stacked two-high in rows. The material handler could easily access this information from the tanks in the upper rows, but not those in the lower rows. Management had determined that it was unsafe for an employee to crawl under the stacked tanks and that instead a crane or forklift should be used to lift the tanks. To gain access to the tanks in the lower rows where there was insufficient space for a forklift to operate, a boom truck crane was employed to lift the top row tank so that another employee could record the necessary information. This method had been used by employees during previous inventories and was an accepted company practice. Previously, three employees performed the inventory: one operated the crane, another did the rigging, and the third wrote down the inventory information. For this inventory, management decided that it would be unnecessary to have a third employee involved, as the operation went just as quickly with two employees. The manager stated that the propane industry typically maintains lean staffing for its operations.

For the current inventory, the service technician was the competent person who had the autonomy to make decisions about how the inventory was done and how the tank lifts should be made. As space between the rows of tanks would not allow room for a forklift to maneuver, he chose to use a crane. He used this particular crane because he was 
familiar with it and had often used it, both at the yard and for customer deliveries. It had been used by him and others during previous inventories. At 47 feet full extension, the crane's boom, according to the general manager, had the longest reach of all their company cranes and was longer than was needed to perform the task at hand.

While using the crane to lift the tanks, the service technician was serving as the crane operator and the material handler was, in addition to writing down the inventory information, serving as the rigger.

On the day of the incident, the victims were using a metal chain as rigging for lifting the tanks. Prior to each lift the material handler attached the chain to the metal lifting lugs located on either side of the tank's top. According to the general manager, the usual company practice was to use nylon rigging straps; he did not know why they were using a metal chain for this task.

The victims spent the day performing the inventory of tanks located in the north part of the company yard. At one point they took a break and went inside because of a heavy rain shower. As it was getting late in the work day, the plant supervisor asked them if they wanted to continue working on the inventory or whether they wanted to stop for the day and start work again in the morning. They decided to continue working and at about 4:30 p.m. went back to doing the inventory. At about 4:30 p.m. the facility supervisor left to go to another company plant. The office staff would usually leave work at about 5 p.m. The victims were the only employees working in the north yard.

Returning to the inventory, the victims continued to work their way up and down the rows of tanks, taking about 5-6 minutes to lift and move a tank and record information and reset the tank on top of the lower tank. They were working in the northwestern section of the yard in tank rows running east to west. The boom truck was positioned facing north with the crane boom extended to the west.

Shortly after 5 p.m., the material handler proceeded to rig an empty approximately $800-$ pound, 320-gallon capacity tank for lifting (see photo 6). He accessed this tank by a narrow gap, perhaps two-feet wide, between two rows of tanks (see photo 7). This tank rested on top of another tank and was the last tank in a row of tanks stacked two-high; it was the furthest tank from the boom truck. Immediately beyond the last tank in these rows was a chain link fence marking the western boundary of the yard. Beyond the fence on land owned by a railroad company was a 3-phase, 7,200 volt overhead power line running north to south. The lines included, in sequence, an eastern-phase, neutral, middle phase, and western phase. The eastern-phase of the three-phase power line was directly above the tank that was being rigged by the material handler prior to being lifted. Though incident investigators did not record the exact distance, they noted that the power line crossed at a diagonal over the yard's perimeter fence in the northwestern 
part of the yard. Photos of the incident scene show that the power lines extended into the yard by only a few feet. This is the only area of the plant yard where power lines cross over into the yard.

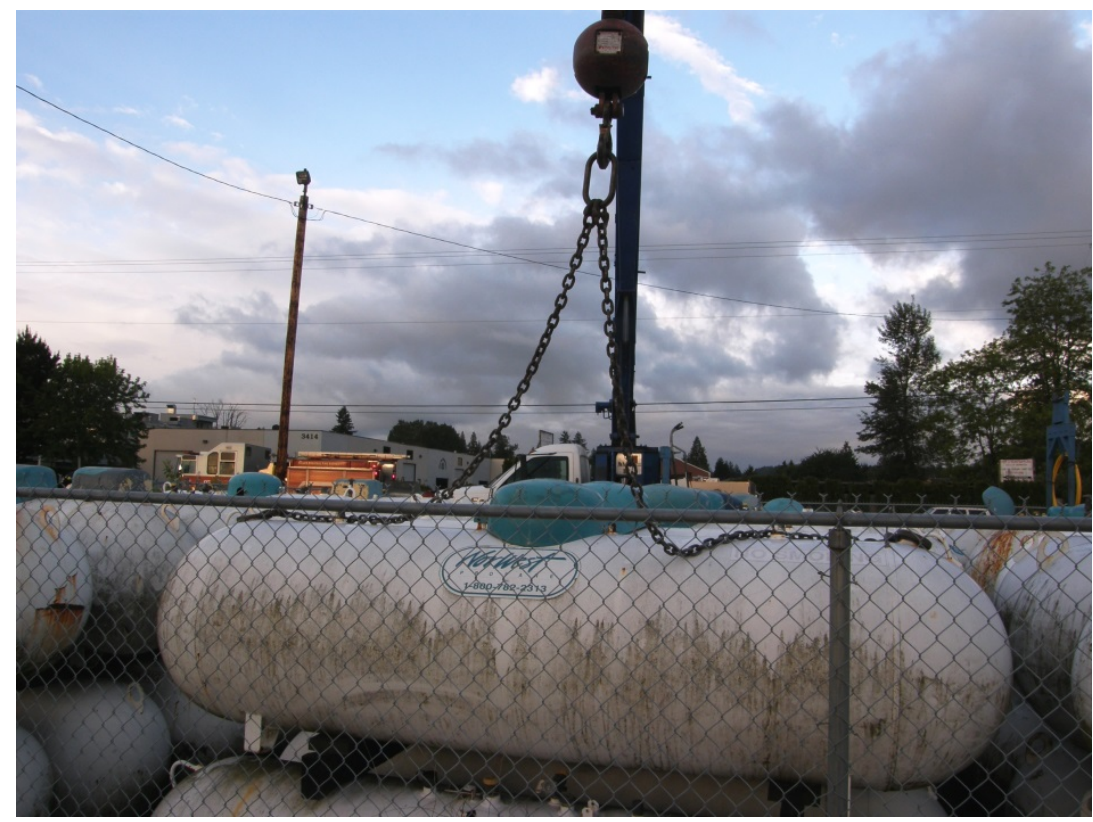

Photo 6. 320-gallon capacity propane bulk storage tank the material handler had rigged prior to the crane boom contacting the overhead power line.

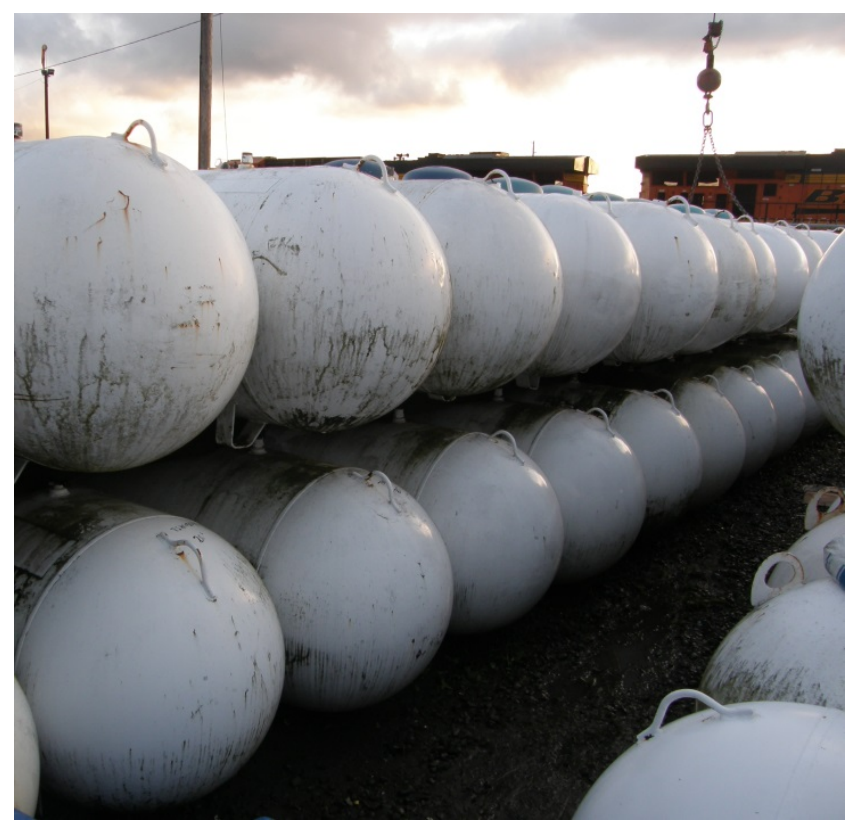

Photo 7. Incident scene showing stacked rows of propane bulk storage tanks being inventoried by the victims. View is from ground level near the boom truck looking toward the tank rigged by the material handler. 
According to the manager, the power lines had been in this location for at least 17 years. He did not believe that any precautions, such as requesting the power utility company or owner of the lines to de-energize the lines or using appropriate distance setbacks for cranes, had ever been taken during this period when employees were operating cranes near these power lines. Subsequent to the incident, the DOSH investigator interviewed employees who stated that they had operated a crane boom within less than 10 feet of power lines at this yard. The general manager stated that neither management nor employees had identified the power lines as a hazard; they had all just taken them for granted and had not recognized their proximity to their work activities with cranes.

After the material handler finished rigging the chains to the tank lifting lugs and load line connection, the service technician proceeded to position the crane's boom for the lift. The tank was 28 feet away from the boom truck. It is unknown whether at this point the service technician was extending out or winching up the boom. The nearest power line to the boom was the eastern phase of the 7,200 volt power line. In its relaxed position this power line wire was 40 feet 9 inches above the ground. As the service technician was positioning the boom, he fully extended it to 47 feet with a 35 degree angle. At this point, the boom tip made contact with the energized eastern phase wire of the power line (see photos 8, 9, 10).

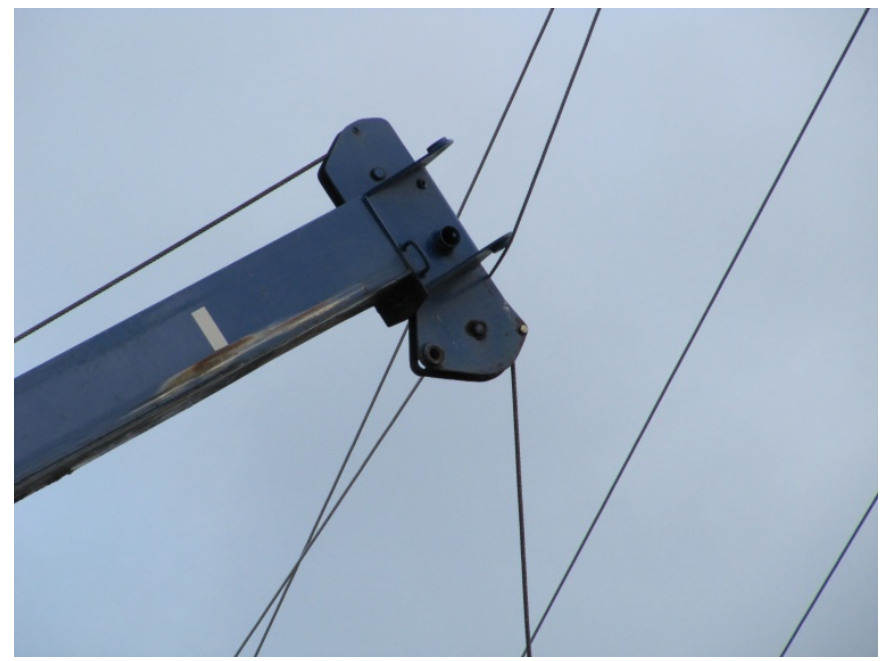

\section{Photo 8. Boom tip contacting power line.}

Electrical current traveled from the power line down the boom to the truck and the metal grating of the crane operator's station where the service technician was standing. According to the medical examiner, the service technician died instantly when he stepped from the station to the ground. With one foot on ground and one foot on the station he created a pathway for the current to move from the crane through his body to the ground. As the electrical current continued to travel through the boom truck's 
deployed outriggers, the ground in the vicinity was also energized. The area where the material handler stood was not energized. He then went toward his coworker, presumably to provide aid, and entered the electrical field where he too was electrocuted.

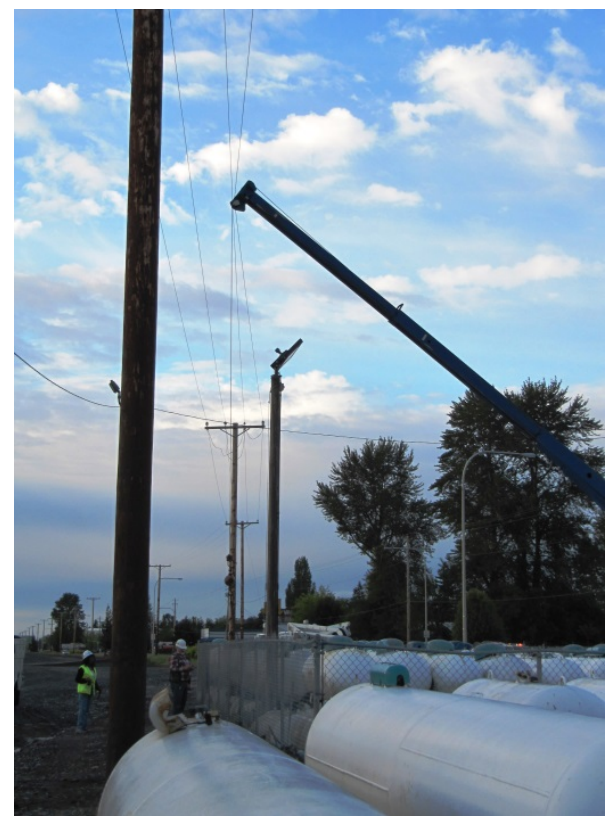

\section{Photo 9. Incident scene with crane boom contacting power line.}

The boom tip remained in contact with the power line, emitting smoke. The intensity of the electrical current caused fire to break out on the boom truck and its tires, the ground area, and adjacent empty propane tanks. Company employees in the office saw smoke and flames. These employees, not knowing what had occurred and fearing explosion of propane gas contained in tanks in the yard, evacuated the building and the company premises. An employee called 911 and spoke with a dispatcher at 5:07 p.m. By 5:11 p.m. first responders from the local fire department were on the scene. Responders blocked off traffic on the adjacent municipal roadway and fire trucks began to apply water to the affected area. Power utility personnel arrived and de-energized and grounded the power lines.

When the incident site was stabilized, first responders and investigative personnel from several agencies and departments arrived at the site. The victims were found next to each other on the ground by the boom truck's left front stabilizer and adjacent to the elevated metal crane operator's station. The medical examiner arrived and pronounced the victims deceased. 


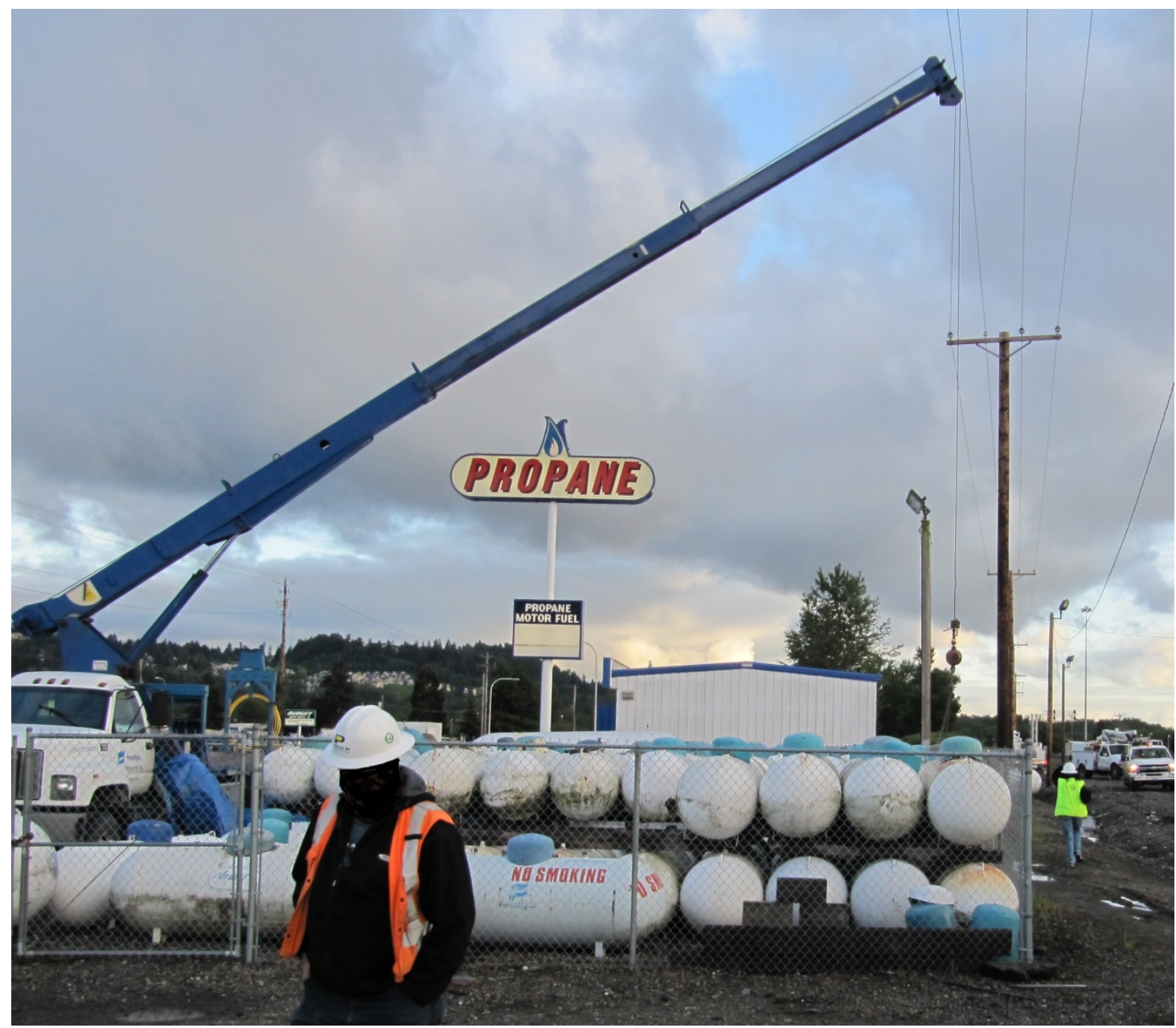

Photo 10. Crane boom tip contacting eastern phase wire of a three-phase 7,200 volt power line. The power lines were located to the west of the yard, and for a short distance inside the yard, and ran north and south. The sequence of the three-phase 7,200 volt power line wires in relationship to the crane boom is eastern phase, neutral, middle phase, and western phase. 


\section{CAUSE OF DEATH}

The medical examiner's office reported that the cause of death for both victims was high voltage electrocution.

\section{CONTRIBUTING FACTORS}

Occupational injuries and fatalities are often the result of one or more contributing factors or key events in a larger sequence of events that ultimately result in the injury or fatality. Washington FACE investigators identified the following factors that may have contributed to the deaths by electrocution of the service technician (crane operator) and the material handler (rigger):

- Configuration and layout of the company yard and storage of propane tanks in relation to overhead power lines situated on adjacent property.

- Failure to adequately recognize the proximity and hazard of overhead power lines to the work area where cranes were being used for material handling tasks.

- Failure to address and mitigate the hazard of electrocution to personnel performing material handling tasks in the vicinity of power lines.

- Failure to maintain minimum safe clearance distance between the overhead power line and the crane.

- Failure to adequately train employees operating cranes and other material handling equipment, riggers, signal persons, and others involved in material handling in the hazards of electrocution by equipment contact with overhead power lines, and in safe work practices to prevent electrical contact.

- Failure to adequately train employees how electrical current works and how they should respond safely, especially would-be rescuers, in the event material handling equipment, hoist lines, loads, rigging, and the surrounding area become energized.

\section{POST-INCIDENT CORRECTIVE ACTIONS TAKEN BY EMPLOYER}

After the incident the employer made changes aimed at preventing future crane electrocution occurrences.

These changes included:

- Conducted site surveys at all service center locations nationally to determine power line locations and voltage.

- Developed training materials addressing overhead power line hazards. 
- Trained employees in hazard recognition and safe operating procedures.

- Required all boom truck operators to be trained and National Commission for the Certification of Crane Operators (NCCCO) certified.

- Moved tanks away from power lines.

- Installed chain barricade $10 \mathrm{ft}$. from power lines.

- Put up signage warning of the electrocution hazard of power lines.

- Sold the incident crane and purchased a crane with a shorter boom, making it less likely that the boom could reach the power line in the tank storage yard.

- Changed how tank inventory is done by keeping records of the tanks as soon as they are returned to the yard so that it is no longer necessary to lift the tanks to obtain inventory information.

- Uses alternative tank lifting and moving methods (forklift, dolly) other than cranes when possible.
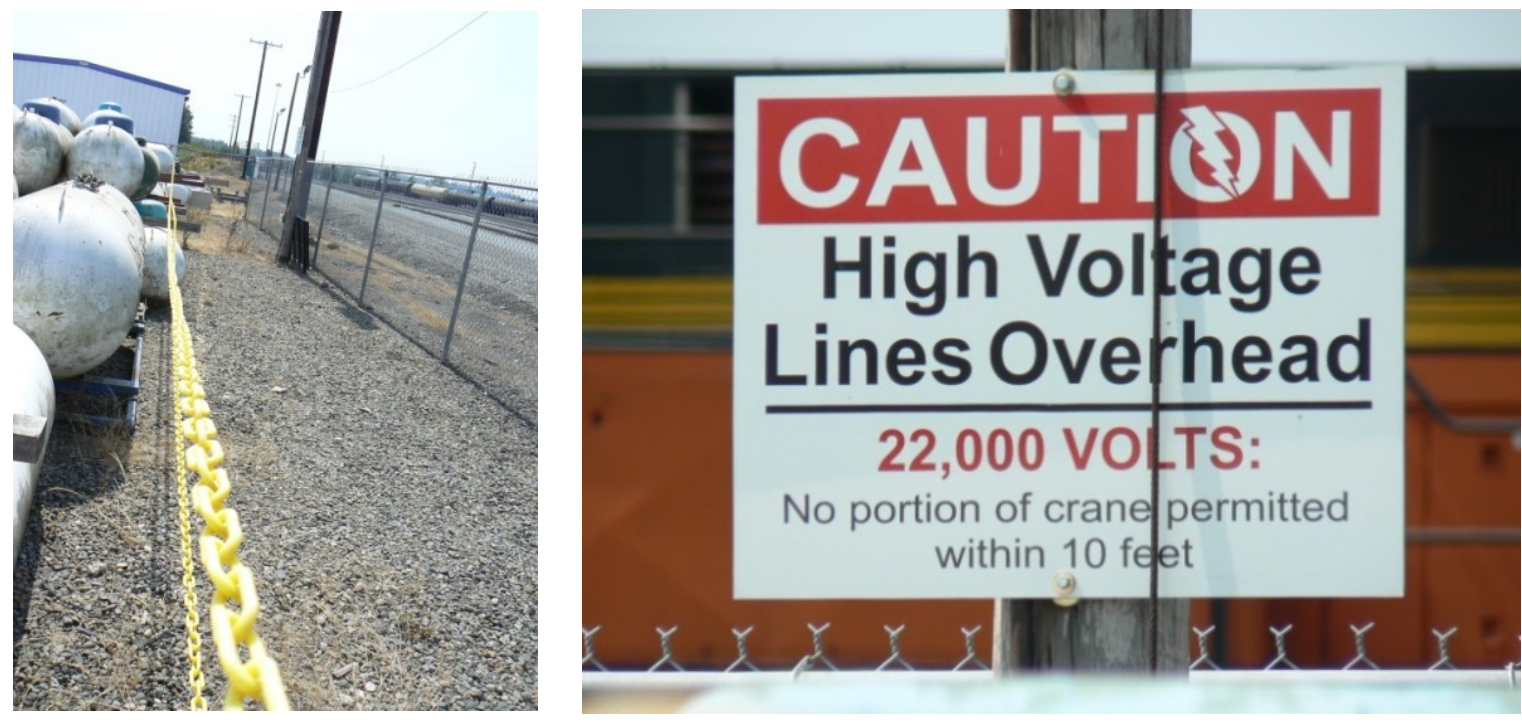

Photos 11 and 12. Employer tank storage yard post-incident. The employer installed a chain barricade ten feet from the overhead power lines and signage to remind crane operators to stay back 10 feet. (The voltage on the sign refers to the cumulative voltage of the 3-phase wires.) 


\section{RECOMMENDATIONS AND DISCUSSION}

\section{Recommendation \#1: Conduct a site survey to identify the locations of overhead power lines and determine whether work tasks could expose crane operators or ground workers performing material handling activities to the hazard of electrocution through boom, rigging, hoist line, or load contact with overhead power lines.}

Discussion: In this incident, a site survey was not conducted by the employer. It is recommended that before employees begin a material handling task involving a crane that employers determine whether workers potentially could be at risk of electrocution from overhead power lines while operating a crane at a company facility or job site. This can be done by surveying a site to determine the location of overhead power lines and their voltage. Depending on site specific circumstances, this survey may be a formal written assessment or a visual one upon arrival at a site. Once the locations of power lines are identified, then decisions should be made by the employer or the crane operator as the competent person on site about the likelihood of workers performing work activities in the vicinity of energized power lines.

Site survey assessments should be made of employer controlled fixed sites, such as the tank storage yard in this incident; residential, commercial, and agricultural customer delivery sites; and the potentially dynamic environment of construction sites.

A significant factor in this incident was the failure by the employer to adequately recognize the proximity of power lines to work areas and the hazard they presented to employees operating cranes. According to the regional manager who was based out of the office at the incident site, the power lines were not viewed as a hazard, because they appeared to be so far away from most work that was being performed in the yard. Also, he stated that no one quite recognized that the power line wires crossed over into the northwest part of the tank storage yard.

A probable incident factor is that the employer as the property lessee inherited the site from a previous tenant that also was a propane seller. This site could be consider a legacy facility, in that they did not design the configuration of the yard in relation to the power lines, but instead made do with what had existed previously, i.e., the location of the power lines, and used the limited yard space as they thought best to carry on operations.

These incident factors, failure to recognize the power line hazard, the configuration of the yard, movement of tanks by cranes in proximity to power lines, as well as inadequate training of employees, led to what could be called a latent condition or latent 
failure. Latent conditions/failures may exist within a company or system and "arise from factors such as organizational culture, management decisions, the design of procedures, or deficiencies in training." ${ }^{29}$ Alternatively, active failures are unsafe acts committed by people. Latent conditions may exist within a company or system for years before they combine with an active failure that may produce an event that could result, for example, in an injury. ${ }^{26}$

In this this incident, the latent conditions/failures allowed for an active failure which consisted of the service technician operating the crane boom in close proximity to and ultimately contacting the power line. It is important that employers uncover the latent conditions/failures within their organizations, so that they may prevent employee injuries or deaths. A site survey for locations of overhead power lines is a useful tool that an employer may use in uncovering latent hazardous conditions to which their employees may be exposed.

After the incident, the employer conducted site surveys of all their service center unit locations across the country. They determined the locations of all power lines and their voltages. They then made national company-wide changes to ensure the safety of their employees (see "post-incident correction actions taken by employer" section of this report on page 17).

\section{Recommendation \#2: Determine measures to be taken so that the hazard of power line electrocution may be avoided, eliminated, reduced, or controlled. Follow existing OSHA regulations and safe work practices.}

Discussion: If after conducting a site survey an employer finds that there are overhead power lines that may present a risk of electrocution to employees, then the employer should determine how to protect employees. Always assume that power lines are energized unless you have confirmation from the power line owner or utility company that the lines have been de-energized and grounded. It is recommended that employers follow existing requirements of the Occupational Safety and Health Administration (OSHA) and OSHA-approved State Plan states, such as Washington State's. These regulatory requirements provide detailed specifications relating to safe work practices concerning the operation of cranes and ground crews working in the vicinity of overhead power lines. ${ }^{19,20,21,22}$

In this incident, the crane operator (service technician) was operating the crane too close to the power line. Employers should ensure that crane operators maintain minimum clearance distance between overhead power lines and the crane and its load. If the voltage of the power line is known, maintain minimum clearance distances as specified by OSHA (see table 1). If the voltage of an overhead power line is unknown, 
stay at least 45 feet away. Table 1 can be used to determine minimum safe working distances for crane operators when working near overhead power lines.

Table 1. Minimum Safe Working Clearance Distances ${ }^{19}$

\begin{tabular}{ll}
\hline Power line voltage, kilovolts (kV) & Minimum safe clearance distance (feet) \\
\hline Up to $\mathbf{5 0}$ & 10 \\
Over $\mathbf{5 0}$ to $\mathbf{2 0 0}$ & 15 \\
Over $\mathbf{2 0 0}$ to $\mathbf{3 5 0}$ & 20 \\
Over $\mathbf{3 5 0}$ to $\mathbf{5 0 0}$ & 25 \\
Over $\mathbf{5 0 0}$ to $\mathbf{7 5 0}$ & 35 \\
Over $\mathbf{7 5 0}$ to $\mathbf{1 , 0 0 0}$ & 45 \\
Over $\mathbf{1 , 0 0 0}$ & $\begin{array}{l}\text { As established by the utility owner/operator or } \\
\text { registered professional engineer who is a qualified } \\
\end{array}$ \\
& person with respect to electrical power \\
& transmission and distribution. \\
\hline
\end{tabular}

Other measures to consider:

- Design or redesign employer controlled premises where cranes or other highreach equipment are used for material handling purposes, so that there is either a reduced or no possibility of crane contact with power lines. These site changes could include relocating work activities away from power lines or moving the power lines. ${ }^{14}$

- Redesign a task so that employees have reduced or no exposure to energized power lines. Consider implementing and evaluating alternative work methods (see photo 15). Assess whether a task can be done differently. In the case of the incident employer, inventory is now done by electronically tracking tanks as they come into the yard, removing the need to lift tanks by a boom truck crane to record the necessary inventory information.

- For specific material handling tasks consider creating a written job hazard analysis (JHA) detailing the specific hazards and safe work procedures to be used to eliminate or reduce employee risk. 


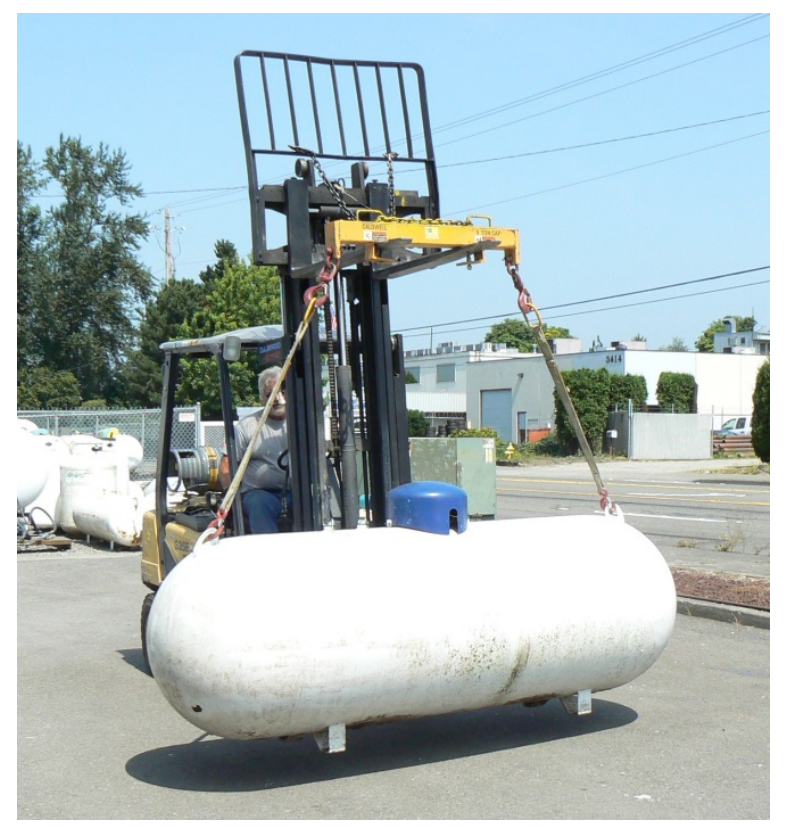

Photo 13: An alternative method of lifting and moving tanks. Propane storage tank being moved by a forklift using a spreader bar and nylon straps attached to the tank's lifting lugs at the employer's yard. According to the employer safety and technical support manual, this method of using rigging attached to lifting lugs to lift and move tanks is used on tanks that are empty or contain no more than $5 \%$ of product. For tanks with defective lugs or containing more than $5 \%$ of product the straps or chains are positioned under the belly of the tank and to the outside of the tank legs.

Recommendation \#3: Develop, implement, and enforce a comprehensive written safety program for all workers. The safety program should include training for all crane operators and ground workers in overhead power line electrocution hazard recognition and safe work procedures. Training should also include crane operator power line visual limitations and perception issues, as well as emergency procedures should power line contact occur.

Discussion: A comprehensive written safety program should be developed that includes training for all employees in recognition of power line electrical hazards and safe work procedures to avoid these hazards. In Washington State, a formal, written Accident Prevention Program (APP) is required of all employers. ${ }^{30}$ Employers should provide their employees both classroom and on-the-job training.

Employee training should include information about issues of visual limitations and perception relating to overhead power lines. While it is impossible to know whether there were any visibility or perception issues that affected the service technician while 
operating the crane, human factors researchers have noted that it is very difficult for crane operators to

- Accurately visually judge clearances between a crane boom or its hoist line and power lines. ${ }^{17}$

- Observe more than one visual target at a time. ${ }^{2,8}$

A partly overcast sky may have affected the service technician's ability to recognize how close the crane's boom was to the power lines because of low contrast.

All employees who operate cranes and material handlers who assist in the operation of cranes should be trained by their employer in the hazards of electrical current and shock and what to do if equipment or its components make contact with an energized overhead power line. ${ }^{19,21}$ If the material handler had been trained to recognize the hazards of electrical shock, perhaps he would not have attempted to approach the service technician. No one should attempt to provide aid to or rescue someone who has suffered an injury as a result of electrical current until the crane is either separated from contact with the power line or the power line has been de-energized and grounded. Rescuers attempting to approach victims who have received electrical shock often become victims themselves when they approach a victim without ensuring that electric current is not still active.

Figure 1 illustrates how electric current flowing from equipment contact with an overhead power line can affect ground workers. This energized zone has the highest concentration of ground current and the highest voltage nearest the crane in contact with the power line and becomes weaker as it radiates out from the point of contact.

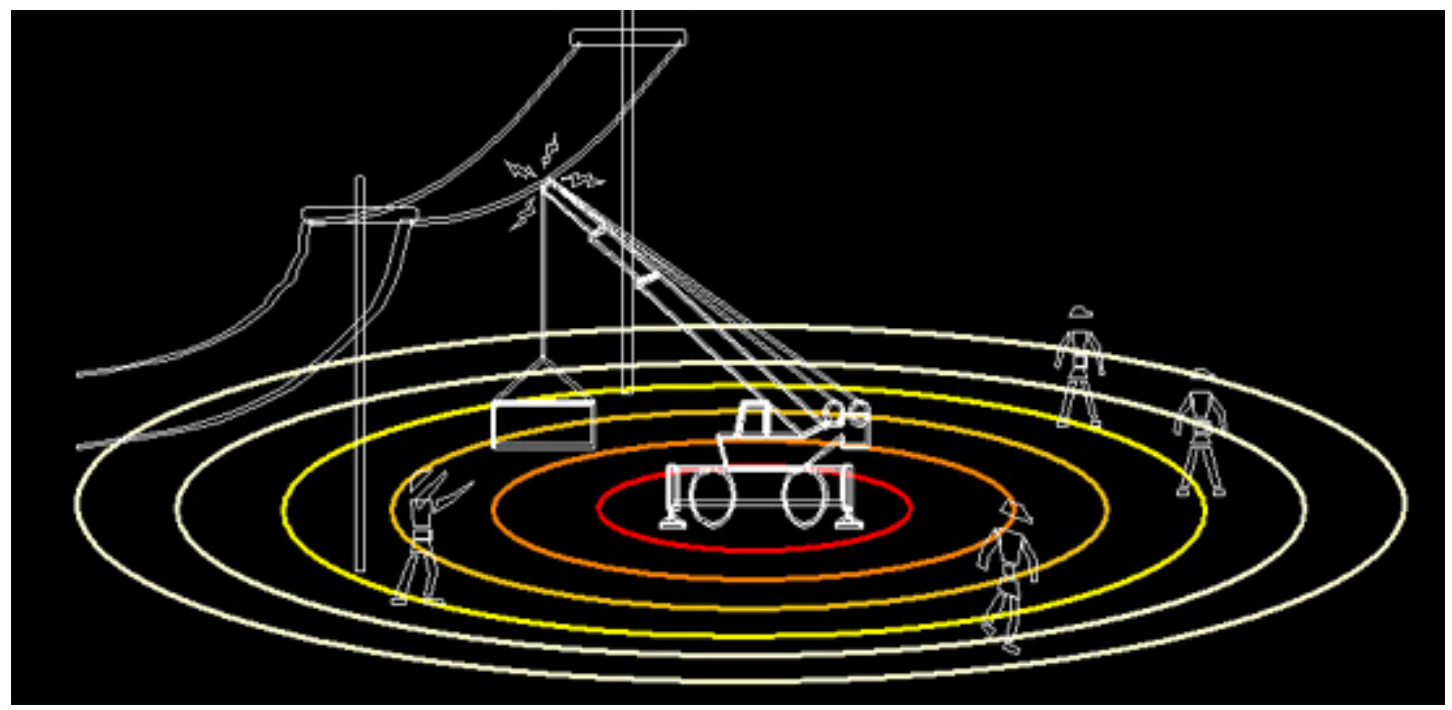

Figure 1: Illustration of how electric current can flow outward through the ground in a ripple pattern from equipment in contact with the power line. 
Recommendation \# 4: Consider purchasing cranes with safety features intended to prevent or minimize the risk of electrocution. Alternatively, consider installing after-market safety accessories.

Discussion: There are a variety of safety accessories available to reduce the possibility of crane operator and ground worker electrocution, such as cage-type boom guards, range control devices, insulating links, and proximity warning devices. But it should be noted that there are various issues with these devices that can make them less than fully reliable. ${ }^{8,27}$ These devices must not substitute for safe work practices such as de-energizing and grounding lines or maintaining safe working distances from power lines. ${ }^{7}$ The safety literature and OSHA state that operators should not expect to rely on these accessories or devices to warn of or protect from power line proximity or contact. Yet these accessories are often recommended as protective measures. OSHA regulations state that cage-type boom guards, insulating links, and proximity warning devices should solely be used as back-up measures and cautions that they are not substitutes for maintaining a safe distance or other safe work practices. These protective devices serve as redundant safeguards that provide a margin of safety to crane operators and ground crews working near power lines. 


\section{REFERENCES AND TRAINING MATERIALS}

1. Weather Underground.

http://www.wunderground.com/history/airport/KSEA/2010/5/26/DailyHistory.html?req cit $\mathrm{y}=\mathrm{NA} \& \mathrm{req}$ state $=\mathrm{NA} \& \mathrm{req}$ statename $=\mathrm{NA} \& M R=1$

2. WorkSafeBC. Human visual limitations and overhead power lines. Human Factors Bulletin 2011-01. http://www2.worksafebc.com/i/posters/2011/HF 11 01.html

3. WorkSafeBC. Worker on Scissor Lift Electrocuted [video]. http://www.youtube.com/watch?v=OATbbDySdug

4. WorkSafeBC. Electrical Safety: Crane Truck Contact [video]. http://www2.worksafebc.com/Publications/Multimedia/Videos.asp?Report|D=37339

5. Washington State Department of Labor and Industries. Investigation Stories: Boom Truck Electrocution [slide show].http://wishatraining.Ini.wa.gov/Training/InvestigationStories/ElectrocutionMobileCraneContactsPow erLines/player.html

6. Propane Education \& Research Council. Mobile Crane Safety in the Propane Industry Training [multimedia program materials], available at: http://www.propanesafety.com/mobile-crane-safety/

7. American Society of Mechanical Engineers (2012). ASME B30.5-2011 - Mobile and Locomotive Cranes - Safety Standard for Cableways, Cranes, Derricks, Hoists, Hooks, Jacks, and Slings.

8. MacCollum, D.V. (2005). Crane Hazards and Their Prevention. American Society of Safety Engineers, Des Plaines, IL.

9. Fatality Assessment and Control Evaluation (FACE) Program (2005). Hispanic Laborer Electrocuted After Boom Truck Contacts Overhead Power Line - North

Carolina. NIOSH in-house FACE report: 2005-02.

http://www.cdc.gov/niosh/face//n-house/full200502.html

10. Fatality Assessment and Control Evaluation (FACE) Program (2005). Hispanic Laborer Electrocuted When Crane Boom or Load Line Contacts 7,200 Volt Overhead Power Line - North Carolina. NIOSH In-house FACE Report: 2005-01.

http://www.cdc.gov/niosh/face/in-house/full200501.html

11. Moore P (1995). NIOSH Alert: Preventing Electrocutions of Crane Operators and Crew Members Working Near Overhead Power Lines. Cincinnati, OH: U.S. Department of Health and Human Services, Public Health Service, Centers for Disease Control and Prevention, National Institute for Occupational Safety and Health, Division of Safety 
Research, DHHS (NIOSH) Publication No. 95-108.

http://www.cdc.gov/niosh/docs/95-108/

12. CDC (1995). Preventing Electrocutions of Crane Operators and Crew Members

Tear-out Sheet. http://www.cdc.gov/niosh/pdfs/95-108sum.pdf.

13. DOL. OSHA Construction eTool: Electrical Incidents.

https://www.osha.gov/SLTC/etools/construction/electrical incidents/powerlines.html

14. American National Standards Institute/American Society of Safety Engineers (2011). ANSI/ASSE Z590.3-2011 - Prevention through Design: Guidelines for Addressing Occupational Hazards and Risks in Design and Redesign Processes. http://webstore.ansi.org/RecordDetail.aspx?sku=ANSI\%2FASSE+Z590.3-2011

15. Construction Safety Association of Ontario (1982). Mobile Crane Manual. Toronto, Ontario, Construction Safety Association of Ontario.

16. Cawley, J.C., Homce, G.T. (2003). Occupational electrical injuries in the United States, 1992-1998, and recommendations for safety research. Journal of Safety Research. 34(3):241-8.

17. Imbeau, D., Paques, J., Bergeron, S., Bourbonniere, R. (1996). Comparison of two methods for judging distances near overhead power lines. International Journal of Occupational Safety and Ergonomics. 2(3):196-211.

http://www.ncbi.nlm.nih.gov/pubmed/10602585

18. Homce, G.T., Cawley, J.C. (2002). An Alarm to Warn of Overhead Power Line Contact by Mobile Equipment. National Institute for Occupational Health and Safety. http://www.cdc.gov/niosh/mining/userfiles/works/pdfs/atwop.pdf

19. Washington Administrative Code. Chapter 296-155 Construction Work, Part L, Cranes, Rigging, and Personnel Lift, WAC 296-155-53408 Power Line Safety http://www.Ini.wa.gov/safety/rules/chapter/155/WAC296-

155.PDF\#WAC $296155 \quad 53408$

20. Washington Administrative Code. Chapter 296-24 General Health and Safety Standards, Part L, Electrical. http://www.Ini.wa.gov/safety/rules/chapter/24/WAC29624.PDF\#WAC 29624957

21. OSHA. 1926 Subpart CC, Cranes and Derricks in Construction. https://www.osha.gov/pls/oshaweb/owasrch.search form?p doc type=STANDARDS\&p toc level=1\&p keyvalue=Construction\#1926 Subpart CC

22. OSHA. 1910 Subpart S, Electrical.

https://www.osha.gov/pls/oshaweb/owadisp.show document?p table=STANDARDS\&p id $=10135$ 
23. Washington State Department of Labor and Industries (2013). Working too close to overhead power lines. DOSH Hazard Alert.

http://www.Ini.wa.gov/safety/hazardalerts/OverheadPowerLines.pdf

24. Washington State Department of Labor and Industries (2012). Deadly power-line contact with cranes. DOSH Hazard Alert.

http://www.Ini.wa.gov/safety/hazardalerts/CranesAndPowerlines.pdf

25. Health and Safety Executive (HSE). Human factors in accident investigations. http://www.hse.gov.uk/humanfactors/topics/core2.pdf

26. Reason, J. (2000). Human error: models and management. British Medical Journal, 320, 768-770. http://www.ncbi.n/m.nih.gov/pmc/articles/PMC1117770/

27. Homce, G. T. et al. (2008). A Performance Evaluation of Two Overhead Power Line Proximity Warning Devices. NIOSH.

http://www.cdc.gov/niosh/mining/works/coversheet165.html

28. OSHA. 1926 Subpart O, Motor Vehicles, Mechanized Equipment, and Marine Operations, Equipment.

https://www.osha.gov/pls/oshaweb/owadisp.show document?p table=STANDARDS\&p id $=10767$

29. Thomas, M.J.W. (2003). Uncovering the origins of latent failures: the evaluation of an organisation's training systems design in relation to operational performance.

Proceedings of the Sixth International Aviation Psychology Symposium. Sydney, Australia: Australian Aviation Psychology Association.

http://www.unisanet.unisa.edu.au/staff/MatthewThomas/Paper/Thomas LatentFailures. $\underline{\mathrm{pdf}}$

30. Washington State Department of Labor and Industries. Accident Prevention

Program. http://www.Ini.wa.gov/safety/topics/atoz/APP/

\section{Investigator Information}

Todd Schoonover has a PhD in Industrial Hygiene from the University of Illinois at Chicago. He is a Certified Industrial Hygienist $(\mathrm{ClH})$ and Certified Safety Professional (CSP). Todd is currently the Principle Investigator for the WA FACE Program.

Christina Rappin has a BAS from the Evergreen State College. She is a Research Investigator with the WA FACE Program.

Randy Clark has a BA from the Evergreen State College. He is a Safety and Health Specialist with the WA FACE Program. 


\section{Washington State FACE Program Information}

The Washington State Fatality Assessment and Control (WA FACE) program is one of many workplace health and safety programs administered by the Washington State Department of Labor \& Industries' Safety \& Health \& Research for Prevention (SHARP) program. It is a research program designed to identify and study fatal occupational injuries. Under a cooperative agreement with the National Institute for Occupational Safety and Health (NIOSH grant\# 5 U60 OH008487-09), WA FACE collects information on occupational fatalities in WA State and targets specific types of fatalities for evaluation. WA FACE investigators evaluate information from multiple sources. Findings are summarized in narrative reports that include recommendations for preventing similar events in the future. These recommendations are distributed to employers, workers, and other organizations interested in promoting workplace safety. NIOSH-funded, statebased FACE programs include: California, lowa, Kentucky, Massachusetts, Michigan, New Jersey, New York, Oregon, and Washington. WA FACE does not determine fault or legal liability associated with a fatal incident. Names of employers, victims and/or witnesses are not included in written investigative reports or other databases to protect the confidentiality of those who voluntarily participate in the program.

Additional information regarding the WA FACE program can be obtained from: Washington State FACE Program www.Ini.wa.gov/Safety/Research/FACE/default.asp

PO Box 44330

Olympia, WA 98504-4330

1-888-667-4277

\section{ACKNOWLEDGMENTS}

This report was reviewed by stakeholders from labor and business communities and various Washington State and Federal worker safety agencies. Though we are unable to acknowledge specific individuals for their contributions to this report, we would like to recognize the following for their help and support of the FACE mission and objectives:

- The employer's representatives

- Division of Occupational Safety and Health (DOSH)

- Federal FACE Program management (NIOSH)

- Safety \& Health Assessment \& Research for Prevention (SHARP) 